\title{
WYKORZYSTANIE FUNDUSZY EUROPEJSKICH W NAUCE ZAWODU NA KIERUNKU TECHNIK OBSŁUGI TURYSTYCZNEJ W ZESPOLE SZKÓŁ SIÓSTR SALEZJANEK IM. JANA PAWŁA II W SUWAŁKACH
}

Abstrakt: Polityka Unii Europejskiej zapewnia szeroki dostęp do edukacji, zgodnie z określonymi priorytetami. Już od pierwszej perspektywy finansowej Unii szkolnictwo było szeroko omawiane i wysoko finansowane. Dzięki temu, szczególnie dzieci i młodzież mają możliwość wyrównywania różnic edukacyjnych oraz wzmocnienie swojej ścieżki zawodowej i płynnego wejścia na rynek pracy. W latach 2007-2013 w UE szczególny akcent kładziono na rozwój szkolnictwa zawodowego i to zarówno na poziomie średniego kształcenia, jak i wyższego. Obecnie nurt ten jest kontynuowany, dodatkowo z możliwością tzw. mobilności uczniów, czyli kształcenia u pracodawców. W artykule przedstawiono trzy autorskie projekty, realizowane w Zespole Szkół Sióstr Salezjanek im. Jana Pawła II w Suwałkach w ramach funduszy europejskich w latach 2010-2017.

Słowa kluczowe: fundusze unijne, POKL, EFS, Erasmus+, młodzież.

USING EUROPEAN FUNDS FOR THE PURPOSE OF PRACTICAL LEARNING THE PROFESSION AT THE COURSE IN TOURISM SERVICES TECHNIQUES AT THE JOHN PAUL II SALESIAN SISTERS' SCHOOL IN SUWAŁKI

Abstract: The policy of the European Union provides a wide access to education, in accordance with priorities. From the first Union financial perspective higher education has been widely discussed and highly funded. In this way, particularly children and young people have the opportunity to align educational differences and strengthen your professional path and a smooth entry into the labour market. Between 2007-2013 in the EU a special accent was put on the development of vocational education and training medium level, and higher. Now this trend is continued, in addition to the possibility. the mobility of students, that is, education on employers. This article presents three proprietary projects, implemented in the Salesian Comprehensive and Vocational School in Suwałki in the framework of European funding over the years 2010-2017.

Keywords: European Union funds, POKL, EFS, Erasmus+, youth.

\section{WSTĘP}

Fundusze unijne w dziedzinie edukacji mają na celu zapewnienie wszechstronnego wsparcia oświaty, szczególnie poprzez tzw. projekty miękkie. Mają one na celu wyrównywanie szans edukacyjnych, podniesienie jakości kształcenia, kompleksowe wsparcie osób defaworyzowanych, sprawne funkcjonowanie systemu oraz zwiększenie możliwości modernizowania placówek oświatowych, programów nauczania, wdrażania i podwyższania jakości kształcenia zgodnie z oczekiwaniami zmieniającej się gospodarki oraz potrzeb rynku pracy. Celem artykułu jest przybliżenie informacji o funduszach UE oraz zaprezentowanie trzech projektów dofinansowanych ze środków europejskich, a realizowanych w Zespole Szkół Sióstr Salezjanek im. Jana Pawła II w Suwałkach w latach 2010-2011 oraz w 2016 i 2017 r. Autorka jako nauczycielka przedmiotów zawodowych turystycznych poszukuje możliwości nowoczesnego kształcenia, w połączeniu z wzbogacaniem strony społecznej i emocjonalnej uczniów zaangażowanych w projekty.

\section{PROGRAM OPERACYJNY KAPITA LUDZKI - INNOWACJE W PRAKTYCZNEJ NAUCE ZAWODU}

Od momentu wprowadzenia w Polsce funduszy strukturalnych dodatkowym źródłem finansowania edukacji stał się Europejski Fundusz Społeczny (EFS). W latach 2004-2006 Polska otrzymywała granty w ramach Sektorowego Programu Operacyjnego Rozwój Zasobów Ludzkich (SPO RZL) oraz Zintegrowanego Programu Operacyjnego Rozwoju Regionalnego (ZPORR). $W$ ramach ZPORR finansowano stypendia dla uczniów pochodzących z obszarów wiejskich i zagrożonych marginalizacją, dzięki czemu mogli oni kontynuować naukę w szkołach wyższych. Rozwinięto także edukację przedszkolną, przygotowano programy rozwojowe dla szkół oraz projekty z zakresu doskonalenia zawodowego nauczycieli. W wielu szkołach dzięki tym środkom powstały pracownie komputerowe.

W perspektywie finansowej 2007-2013 programowanie i wdrażanie projektów odbywało się głównie w ramach Programu Operacyjnego Kapitał Ludzki 
(PO KL), wspieranego przez Europejski Fundusz Rozwoju Regionalnego (EFRR), skierowanego na inwestycje $\mathrm{w}$ infrastrukturę $\mathrm{w}$ dziedzinie edukacji. Na działania PO KL przewidziano blisko 2,8 mld euro, a ich wykorzystanie możliwe było dzięki działaniom w dwóch priorytetach: Priorytet III. „Wysoka jakość oświaty", którego budżet wynosił $794 \mathrm{mln}$ euro oraz Priorytet IX. „Rozwój wykształcenia i kompetencji w regionach" z budżetem $1982 \mathrm{mln}$ euro. Priorytet III prowadzony przez Ministerstwo Edukacji Narodowej był systemowy, służył m.in. wdrażaniu reformy podstawy programowej kształcenia ogólnego oraz podstaw programowych szkolnictwa zawodowego. Za Priorytet IX odpowiadały samorządy wojewódzkie nastawione na wspieranie indywidualnych osób. Dzięki temu, rozbudowano sieć przedszkoli, wdrażano projekty mające na celu wyrównywanie szans edukacyjnych na każdym poziomie edukacyjnym, a także podnoszenie jakości szkolnictwa zawodowego. Program Operacyjny Kapitał Ludzki umożliwiał wykorzystanie potencjału zasobów ludzkich poprzez podnoszenie kompetencji i zdobywanie kwalifikacji wymaganych na rynku pracy, współpracę z przedsiębiorstwami regionalnymi czy zmniejszanie obszaru wykluczenia społecznego, szczególnie osób z terenów peryferyjnych. Istotnym elementem były działania zmierzające do rozwoju potencjału dydaktycznego szkół.

Przykładem kompleksowego wsparcia uczniów jest autorski projekt „Format przyszłości” realizowany przez Zespół Szkół Sióstr Salezjanek im. Jana Pawła II w Suwałkach współfinansowany przez Unię Europejską w ramach Europejskiego Funduszu Społecznego Programu Operacyjnego Kapitał Ludzki, Priorytet IX. "Rozwój wykształcenia i kompetencji w regionach", Działanie 9.2. Podniesienie atrakcyjności i jakości szkolnictwa zawodowego dofinansowany przez Urząd Marszałkowski Województwa Podlaskiego, który był realizowany od października 2010 do grudnia 2011 r. Myśl o złożeniu wniosku o dofinansowanie zrodziła się po analizie zasobów dydaktycznych dostępnych w szkole oraz rozeznaniu rynku produktów edukacyjnych. Autorce projektu zależało, aby zapewnić uczniom praktyczną naukę zawodu, którą można skonfrontować z nauczanymi przedmiotami teoretycznymi. Celem projektu była odpowiedź na problemy i potrzeby zdiagnozowane na podstawie szkolnych danych o uczniach, opinii kadry pedagogicznej oraz pracodawców branży turystycznej $\mathrm{w}$ regionie uzyskanych z ankiet mających odzwierciedlić potrzeby rynku pracy.

W terminie 21.11.2010-29.01.2011 r. autorka przeprowadziła badania ankietowe wśród 30 przedsiębiorców turystycznych $\mathrm{z}$ województwa podlaskiego, warmińsko-mazurskiego oraz pomorskiego. Badanie miało na celu zdefiniowanie umiejętności uczennic i uczniów przebywających na praktykach zawodowych $\mathrm{u}$ badanych przedsiębiorców oraz oczekiwań pracodawców w zakresie obsługi klienta, urządzeń biurowych oraz podstawowych umiejętności praktykanta. Badani przedsiębiorcy wskazali, że praktyka zawodowa mogłaby odbywać się głównie w dziale obsługi klienta, ponieważ praktykantom brakuje doświadczenia $\mathrm{w}$ profesjonalnej obsłudze turysty, oraz dziale marketingu i księgowości. Uczennice i uczniowie podczas odbywania praktyki zawodowej powinni według pracodawców umieć obsługiwać przede wszystkim programy Microsoft (Word, Excel, Outlook, Power Point). Zdaniem pracodawców praktykant powinien władać językiem angielskim, niemieckim, rosyjskim przynajmniej w stopniu komunikatywnym. Wskazywano, że uczniowie powinni umieć obsługiwać telefon, fax i urządzenie wielofunkcyjne oraz w mniejszym stopniu inne sprzęty biurowe, takie jak laminator czy kserokopiarka. Przedsiębiorcy określili, że oczekują od uczennic i uczniów przychodzących na praktykę umiejętności pisania pism urzędowych, układania programów imprez turystycznych, znajomości opracowywania folderu i ulotki informacyjnej oraz nowych pomysłów na wycieczki turystyczne.

Badani wskazali również najczęstsze problemy, jakie występują w czasie odbywania praktyki. Są to m.in. nieumiejętność profesjonalnej obsługi turysty, wynikająca głównie z nieśmiałości i braku odwagi, zwłaszcza w przełamywaniu barier językowych.

Uzasadnieniem realizacji projektu była niska jakość kształcenia wynikająca $\mathrm{z}$ braku nowoczesnych programów do praktycznej nauki zawodu, duża dysproporcja pomiędzy wiedzą teoretyczną i praktyczną oraz chęć wyrównywania braków edukacyjnych. Głównym celem projektu było więc podniesienie kwalifikacji zawodowych w turystyce wszystkich ówczesnych 47 uczniów (7 uczniów, 40 uczennic), co miało nastąpić dzięki skuteczniejszym formom kształcenia praktycznego, wzmocnieniu kompetencji kluczowych w dziedzinie języka angielskiego jako zawodowego i informatyki. Projekt był kompatybilny z projektami ówczesnej reformy szkolnictwa zawodowego oraz programem rozwoju szkoły. Dzięki dofinansowaniu możliwe było wprowadzenie wielu działań wspierających edukację młodzieży kształcącej się na kierunku technik obsługi turystycznej. Do projektu zakwalifikowano wszystkich uczniów tego kierunku. W ramach realizacji projektu zaplanowano organizacje wyjazdów dydaktycznych nastawionych na pomoc uczniom w procesie tworzenia oferty turystycznej, wyboru miejsc docelowych, wskazanie rodzajów turystyki, które w naszym regionie nie były spopularyzowane, czyli turystyki biznesowej i medycznej. Podczas wyjazdów uczniowie zwiedzali hotele, zakłady uzdrowiskowe, odbywali spotkania $\mathrm{z}$ przedstawicielami 
obiektów turystycznych, mieli szansę obserwacji pracowników obsługi ruchu turystycznego, zapoznawali się z dokumentacją.

Innowacyjnym rozwiązaniem, które wówczas powstało i funkcjonuje do dziś, jest szkolne biuro turystyczne Sales Tour. Jego ideą jest symulacja, czyli pozorowanie pracy rzeczywistego biura turystycznego, w którym wszystkie działania są identyczne z pracami prawdziwej firmy, z wyjątkiem konkretnych towarów i pieniędzy. Biuro „sprzedaje" wycieczki turystyczne innym firmom symulacyjnym, a uczniowie dokonuja zakupu produktów oferowanych przez polskie i zagraniczne placówki. W ramach praktycznej nauki zawodu uczniowie wykonują ćwiczenia w dziale obsługi klienta, marketingu oraz księgowości. Uczeń ma szansę sprawdzenia swoich umiejętności i poznania zakresu obowiązków w każdej specjalności. Dzięki przynależności biura do Polskiej Centrali Firm Symulacyjnych CENSYM, występują niezliczone możliwości rozwoju własnej działalności poprzez dostęp do wszystkich polskich i zagranicznych firm symulacyjnych zrzeszonych w sieci Europen-Pen International. Sieć skupia ponad 7,5 tys. firm symulacyjnych w 42 krajach europejskich. Istnieje także możliwość udziału w targach firm symulacyjnych, np. w Pradze, podczas których można spotkać wielu chętnych i zaangażowanych do współpracy uczniów i nauczycieli. Centrala zapewnia sprawne funkcjonowanie $\mathrm{w}$ sieci, gdyż pełni funkcje urzędów niezbędnych w transakcjach między firmami oraz instytucjami, takich jak: Bank Polski, Poczta, ZUS, Urząd Statystyczny, Urząd Skarbowy czy Sąd Rejonowy. Ponadto firmom symulacyjnym nadaje numery NIP, REGON, EORI oraz wpis do KRS.

Szkolne biuro turystyczne pozwala na wdrażanie dokumentacji turystycznej, opanowanie umiejętności pracy na poszczególnych stanowiskach biurowych, samodzielności czy odpowiedzialności za powierzone zadanie. W dziale obsługi klienta m.in. programuje się i przygotowuje oferty turystyczne wraz z prowadzeniem pełnej dokumentacji. W dziale księgowości następuje kalkulacja, prowadzenie ewidencji księgowej, również kadrowej i płacowej, zaś w dziale marketingu zwraca się szczególną uwagę na pozyskiwanie nowych klientów krajowych i zagranicznych oraz organizowanie działań promocyjnych i reklamowych. Sales Tour działa w zakresie obsługi turystycznej, organizacji imprez turystycznych krajowych i międzynarodowych oraz udzielania informacji turystycznej. Efektem pracy jest poprawa znajomości słownictwa branżowego, umiejętność tworzenia dokumentacji turystycznej w języku polskim i angielskim. Z perspektywy sześciu lat po zakończeniu projektu należy stwierdzić, że pozyskane środki trwałe oraz branżowe programy komputerowe są wykorzystywane przez kolejnych uczniów (fot. 1-3). Naszym absolwentom projekt zapewnił dobry start $\mathrm{w}$ dorosłe życie.

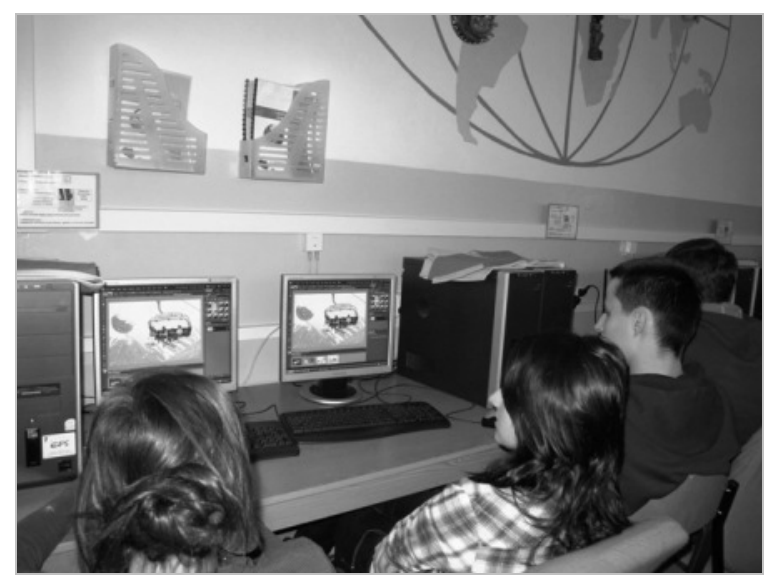

Fot. 1. Zajęcia w Sales Tour

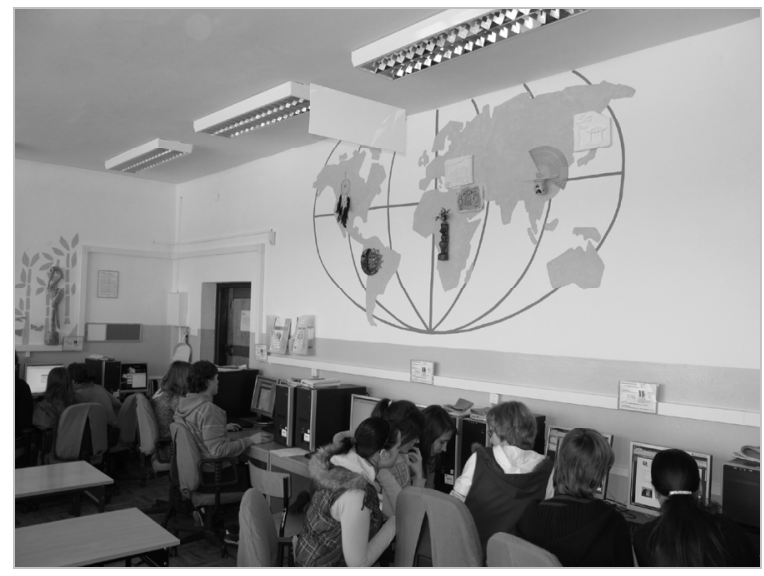

Fot. 2. Zajęcia w Sales Tour

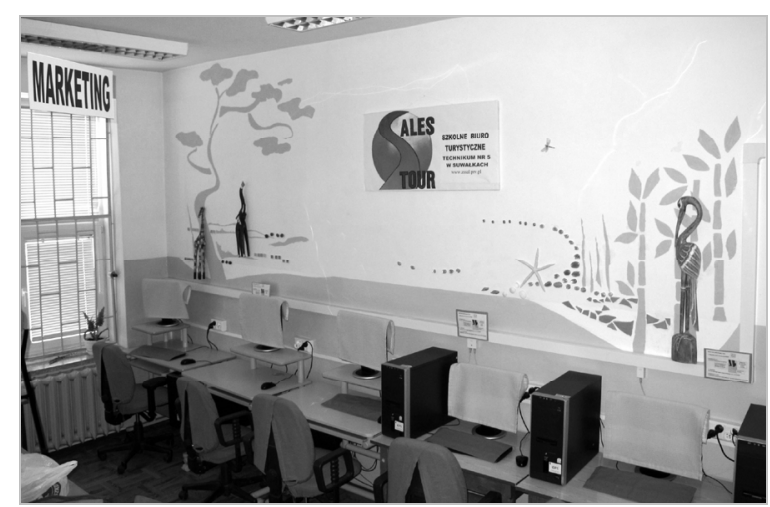

Fot. 3. Sala zajęć w Sales Tour Źródło fot. 1-3: J. Kalejta

\section{KSZTALCENIE ZAWODOWE A OCZEKIWANIA PRACODAWCÓW}

Perspektywa finansowa Unii Europejskiej na lata 2014 -2020 określa cele tematyczne, które warto wyeksponować w składanych wnioskach, są to: „Wspieranie zatrudnienia i mobilności zawodowej pracowników, wspieranie włączenia społecznego i walka z ubóstwem 
Tab. 1. Przebieg praktyk zawodowych przygotowany przez ankietowanych przedsiębiorców (12)

\begin{tabular}{|l|c|c|}
\hline \multicolumn{1}{|c|}{ Przebieg praktyk } & \multicolumn{2}{c|}{ Liczba odpowiedzi } \\
\cline { 2 - 3 } & \multicolumn{2}{c|}{ tak } \\
\hline Praktykant miał możliwość sprawdzenia swojej wiedzy w praktyce & 12 & 0 \\
\hline Odbyta praktyka pozwala wejść uczniom bez stresu na rynek pracy & 6 & 4 \\
\hline Po zakończeniu praktyki uczeń przekazał uwagi w sprawie jej organizacji opiekunowi praktyk & 7 & 4 \\
\hline $\begin{array}{l}\text { Podczas praktyki uczeń przygotowywał pod opieką pracownika samodzielne programy imprez } \\
\text { turystycznych, wypełniał dokumenty itp. }\end{array}$ & 10 & 2 \\
\hline Praktykant potrafił praktycznie zastosować wiedzę teoretyczną uzyskaną podczas nauki w szkole & 10 & 2 \\
\hline Praktykant poznał specyfikę działania podmiotu, w którym odbywał praktykę & 12 & 0 \\
\hline $\begin{array}{l}\text { To, czego uczą się uczniowie na zajęciach teoretycznych jest przydatne dla ich dalszego rozwoju } \\
\text { zawodowego }\end{array}$ & 9 & 2 \\
\hline Uczniowie uczestniczyli w codziennym życiu firmy & 9 & 3 \\
\hline W czasie praktyki uczniowie mogli tylko obserwować, jak wykonywana jest praca w jednostce & 7 & 5 \\
\hline W czasie praktyki obowiązywały uczniów sztywne godziny czasu pracy & 6 & 6 \\
\hline W ramach praktyki praktykanci zwiedzili działy firmy /działy - oddziały w instytucji & 10 \\
\hline $\begin{array}{l}\text { Uczniowie zapoznali się z oprogramowaniem/programami wykorzystywanymi w firmie/ } \\
\text { instytucji }\end{array}$ & 9 & 1 \\
\hline Uczniowie wykonywali te same prace, co inni pracownicy & 3 \\
\hline Zapoznano uczniów z przepisami BHP i higieny pracy obowiązujące w zakładzie & 9 & 3 \\
\hline Zdobyte podczas praktyki umiejętności powinny okazać się przydatne w pracy zawodowej & 12 & 0 \\
\hline
\end{tabular}

Źródło: badania własne przeprowadzone w 2015 r.

Tab. 2. Oczekiwania przedsiębiorców od praktykantów

\begin{tabular}{|l|c|c|}
\hline \multicolumn{1}{|c|}{ Oczekiwania względem uczniów } & \multicolumn{2}{c|}{ Liczba odpowiedzi } \\
\cline { 2 - 3 } & tak & nie \\
\hline Powinni mieć bogatą wiedzę teoretyczną & 10 & 2 \\
\hline Powinni mieć doświadczenie w praktyce i umiejętność zastosowania wiedzy teoretycznej & 10 & 1 \\
\hline Powinni nieć umiejętności pracy w zespole & 11 & 1 \\
\hline Powinni mieć opanowaną obsługę wypełniania/uzupełniania niezbędnej do pracy dokumentacji & 7 & 5 \\
\hline Powinni posiadać umiejętność adaptacji do nowych warunków & 12 & 0 \\
\hline Powinni mieć chęci do samodokształcania się & 12 & 0 \\
\hline Powinni wykazywać się samodzielnością w podejmowaniu decyzji & 12 & 0 \\
\hline Powinni mieć umiejętności podejmowania dodatkowych zajęć & 11 & 1 \\
\hline Powinni posiadać umiejętności analityczne i potrafić sporządzać raporty/projekty itp. & 9 & 3 \\
\hline Powinni wykazywać się lepszą znajomością języków obcych & 8 & 2 \\
\hline
\end{tabular}

Źródło: badania własne przeprowadzone w 2015 r.

oraz inwestowanie w edukację, umiejętności i uczenie się przez całe życie". Obecne dotacje mają na celu wsparcie oraz przygotowanie uczniów i absolwentów do funkcjonowania we współczesnej rzeczywistości poprzez zapewnienie im wykształcenia zgodnego z wymogami rynku pracy. Dotacje unijne na szkolenia możliwe są do uzyskania $\mathrm{w}$ ramach programu krajowego Program Operacyjny Wiedza. Edukacja. Rozwój (PO WER) oraz dla Regionalnych Programów Operacyjnych w każdym z województw.

Program Operacyjny WER to następca Programu Operacyjnego Kapitał Ludzki, w którym działania skierowane są szczególnie na:

- poprawę funkcjonowania i zwiększenie wykorzystania systemu wspomagania szkół w zakresie kompetencji kluczowych uczniów niezbędnych do poruszania się na rynku pracy;
- wypracowanie mechanizmów umożliwiających nawiązanie $\mathrm{i}$ prowadzenie dialogu $\mathrm{z}$ pracodawcami na rzecz dostosowania kształcenia zawodowego do potrzeb rynku pracy;

- modernizację treści i metod kształcenia zawodowego $\mathrm{w}$ celu ich dostosowania do zmieniającej się sytuacji na rynku pracy;

- doskonalenie systemu egzaminów zawodowych we współpracy z pracodawcami;

- wypracowanie rozwiązań w zakresie współpracy szkół zawodowych z uczelniami wyższymi.

Programy regionalne otrzymują wsparcie na inicjowanie współpracy szkół z pracodawcami, wyposażenie szkół i placówek dydaktycznych w nowoczesny sprzęt i materiały dydaktyczne, utworzenie i rozwój ukierunkowanych branżowo Centrów Kształcenia Praktycznego, które mają powiązać ze sobą pracodaw- 
ców i szkoły, oraz wsparcie uczestników kształcenia zawodowego, także doskonalenia umiejętności i kompetencji zawodowych nauczycieli.

W roku 2015, dokładnie rok przed aplikowaniem o środki unijne, autorka ponownie zaproponowała pracodawcom udział w ankiecie. Wzięło w niej udział 12 lokalnych właścicieli przedsiębiorstw turystycznych. W obu przypadkach badań ankietowych lokalnym i regionalnym pracodawcom działającym w sferze turystki zadano pytania dotyczące jakości kształcenia teoretycznego w szkole, umiejętności bieżących i oczekiwanych od pracodawców, zakresu realizacji praktyk, terminu trwania, zasad organizacji praktyk w kolejnych latach. Ankieta składała się z pytań otwartych i zamkniętych. Poniżej przedstawione zostały dwa przykładowe pytania $\mathrm{z}$ odpowiedziami pracodawców. Z tab. 1 można wyczytać jak do przeprowadzenia praktyk przygotowali się przedsiębiorcy (niektóre odpowiedzi nie stanowią 100\%, ze względu na brak odpowiedzi). Kolejna część ankiety skierowana była na oczekiwania pracodawców od praktykantów. Wyniki ukazuje tab. 2.

Według pracodawców, uczniowie szukający pracy w zawodzie związanym $\mathrm{z}$ kierunkiem kształcenia powinni być przygotowani do podjęcia technicznych prac terenowych (odnowa szlaków turystycznych, inwentaryzacja szlaków), przeprowadzania ankiet z turystami, oprowadzania wycieczek $\mathrm{w}$ terenie (posiadanie wiedzy o oprowadzanym terenie). Ze względu na sezonowość lokalnej oferty turystycznej, pracodawcy w szczególności przyjmują uczniów na praktyki w terminie maj-wrzesień.

Wychodząc naprzeciw oczekiwaniom pracodawców, ale też potrzebom kształtowania umiejętności zawodowych uczniów w 2016 r. Zespół Szkół Sióstr Salezjanek w Suwałkach aplikował o kolejne dofinansowanie w ramach konkursu Zarządu Województwa Podlaskiego jako instytucji zarządzającej Regionalnym Programem Operacyjnym Województwa Podlaskiego na lata 2014-2020 ze środków Unii Europejskiej. Dzięki otrzymaniu funduszy w terminie 13.06.-30.11. 2016 r. był realizowany projekt pt. „Wykształcony stażysta - turystyczny specjalista”, współfinansowany ze środków Unii Europejskiej w ramach Priorytetu III „Kompetencje i kwalifikacje”, Działanie 3.3. Kształcenie zawodowe młodzieży na rzecz konkurencyjności podlaskiej gospodarki, Poddziałanie 3.3.1. Kształcenie zawodowe młodzieży na rzecz konkurencyjności podlaskiej gospodarki - poza ZIT BOF.

W ramach tego projektu 30 uczennic i sześciu uczniów kształcących się na kierunku technik obsługi turystycznej (czyli 100\% uczniów) realizowało staże zawodowe w wymiarze minimum 150 godzin na osobę. Celem projektu było podniesienie kompetencji zawodowych wszystkich 36 uczniów poprzez realizację staży zawodowych, wykraczających ponad wymiar praktyk zawodowych objętych podstawą programową. Jednocześnie projekt skierowany był na podniesienie kwalifikacji zawodowych dwóch nauczycielek zawodu poprzez realizację staży zawodowych w wymiarze minimum 40 godzin w ciągu dwóch tygodni. Wyjazdy realizowane były od 26.06. do 22.08.2016 r. Stażyści mieli szansę samodzielnego wyboru przedsiębiorstwa turystycznego na terenie całej Polski, można było wybrać spośród hoteli, biur podróży, instytucji związanych z turystyką. Z opcji wyjazdu skorzystało 20 osób, które odbyły staże w wysoko kategoryzowanych hotelach w Gdańsku, Sopocie, Władysławowie, Karpaczu, Krakowie, Ełku, informacji turystycznej w Giżycku oraz w okolicach Suwałk i samym mieście (fot. 4). W regionie uczniowie realizowali staże w suwalskich hotelach i okolicznych obiektach noclegowych, Urzędzie Miejskim w Suwałkach, Muzeum Okręgowym w Suwałkach, oraz wielu biurach turystycznych w naszym mieście. Staże trwały od sześciu do ośmiu godzin dziennie.

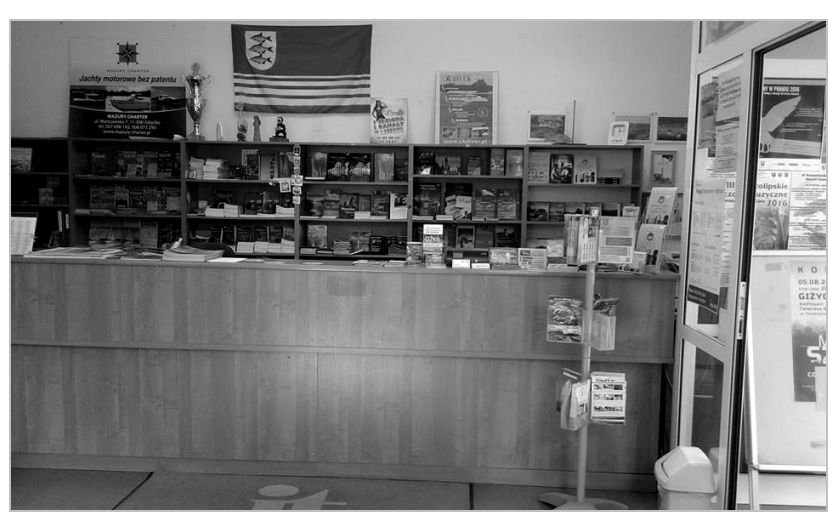

Fot. 4. Jedno z miejsc stażu

- Centrum Informacji Turystycznej w Giżycku Źródło: G. Mackiewic

Przed wyjazdem każdy uczestnik stażu podpisał indywidualną umowę zawartą pomiędzy nim a pracodawcą przyjmującego na staż oraz szkołą. Umowy zawierały szczegółowy opis predyspozycji danej osoby oraz program stażu. Każdy z beneficjentów projektu miał zapewnione świadczenia, tj. strój służbowy, materiały biurowo-piśmiennicze oraz pen drive'a. Stażystom wyjeżdżającym poza Suwałki zapewniono noclegi, pełne wyżywienie oraz bilety przejazdów do i z miejsca stażu, wraz z możliwością jednokrotnego powrotu do miejsca zamieszkania, oraz bilety komunikacji miejskiej. Uczennice i uczniowie pozostający w Suwałkach i okolicach otrzymali wsparcie w postaci codziennego obiadu oraz opłacenia przejazdów i biletów komunikacji miejskiej.

Obowiązkiem uczestnika było bieżace uzupełnianie dzienniczka stażu. Każdy stażysta otrzymał na zakończenie stażu certyfikat potwierdzający jego od- 
bycie wraz $z$ referencjami od pracodawców. Po zakończonych stażach uczniowie uzyskali stypendium stażysty.

Koordynatorka projektu, na początku i pod koniec jego realizacji, przeprowadziła ankiety wśród zaangażowanej młodzieży. Uczniowie w odpowiedziach na dziewięć pytań otwartych szeroko opisywali swoje oczekiwania, wszystkie były związane z poszerzeniem wiedzy branżowej, nabyciem doświadczenia zawodowego, zwłaszcza dotyczącego kontaktu z gościem, obsługi klientów gości, znajomości sposobów pracy, wykonywania pracy typowej dla pracownika obsługi ruchu turystycznego, recepcjonisty i kelnerki, umiejętności układania sztućców, szkolenia języka angielskiego jako zawodowego, przyglądania się funkcjonowaniu obiektów turystycznych od zaplecza, zapoznania się $\mathrm{z}$ programami wspomagającymi pracę w branży, poznania prac biurowych, doskonalenia nauczonych umiejętności. Dla uczniów istotne było także nabycie lub kształcenie cech, takich jak: dyscyplina, asertywność, cierpliwość, sumienność, punktualność, umiejętność pracy w stresujących warunkach. Z ankiet wynika, że po realizacji staży wszyscy beneficjenci projektu nabyli nowe kompetencje, przydatne w zawodzie oraz nowe umiejętności, takie jak: obsługa kasy fiskalnej, zasady obsługi gości itp. Efektem projektu z pewnością będzie zwiększenie szansy zatrudnienia $\mathrm{w}$ branży turystycznej. Istotna była dwukrotna możliwość spotkania $\mathrm{z}$ regionalnymi pracodawcami na początku oraz na podsumowanie projektu. Z ankiet wynika, że projekt przyniósł korzyści uczniom, pracodawcom, a także nauczycielom zawodu uczącym w naszej szkole. Badanie pracodawców uczestniczących w omawianym projekcie wykazało, że docenili oni umiejętności teoretyczne uczniów, zwracali uwagę na chęć pozyskiwania przez nich wiedzy. Ponadto pracodawcy zauważyli, że młodzież chętnie inicjowała różne pomysły, pracowała w zespole, była odpowiedzialna za powierzone zadania do wykonania. Wartość projektu wynosiła: 219 012,10 zł, zaś dofinansowanie: 208 061,49 zł.

\section{MOBILNOŚĆ UCZNIÓW - KSZTALCENIE U PRACODAWCÓW W EUROPIE}

Głównym celem projektów PO WER w zakresie kształcenia i szkoleń zawodowych jest rozwój kompetencji zawodowych i kluczowych poprzez realizację działań polegających na mobilności ponadnarodowej. Jednym z beneficjentów Programu Operacyjnego Wiedza. Edukacja. Rozwój jest Fundacja Rozwoju Systemu Edukacji (FRSE). W kraju za funkcjonowanie Erasmus+ odpowiada Polska Narodowa Agencja. FRSE stosuje się do określonego przez UE „Planu działań Unii Europejskiej wobec młodzieży na lata 2016-2018". Dokument ma na celu podkreślanie znaczenia edukacji wśród młodzieży, szczególnie zagrożonej marginalizacją w społeczeństwie. W Planie zwrócono uwagę na łączenie podstawowych wartości społecznych, ułatwienie młodzieży wchodzenie $\mathrm{w}$ dorosłość, odnalezienia się na rynku pracy. Funkcjonujący od trzech lat program Erasmus+ cieszy się dużym zainteresowaniem. Fundacja wspiera projekty z zakresu tzw. mobilności (wyjazdów) kadry edukacji szkolnej, zagranicznych staży dla uczniów i absolwentów szkół zawodowych, mobilności studentów z niepełnosprawnością oraz znajdujących się $\mathrm{w}$ trudnej sytuacji finansowej czy szkolenia kadry kształcenia zawodowego.

W roku 2014 zostało złożonych około 4 tys. wniosków, dofinansowano 1,4 tys. projektów, przeznaczając 102 mln euro. Największa pula przypadła na sektor szkolnictwa wyższego, na praktykę wyjechało 16,8 tys. studentów. W 2015 r. dofinansowano 1,2 tys. projektów, gdzie obok szkolnictwa wyższego inicjatywy zgłaszały szkoły i instytucje związane z kształceniem młodzieży.

Warto dodać, że dzięki współpracy Fundacji Rozwoju Systemu Edukacji z Ministerstwem Rozwoju możliwe jest finansowanie projektów PO WER w ramach sektorów szkolnictwa wyższego, edukacji szkolnej i kształcenia zawodowego, co zwiększa liczbę otrzymanych dotacji. Dzięki takiemu rozwiązaniu udało się dofinansować blisko 3,5 tys. projektów w latach 2014 i 2015. Całkowity budżet UE na działania Erasmus+ na lata 2014-2020 wynosił 14,7 mld euro. Budżet programu Erasmus+ na rok 2016 wynosił 2,2 mld euro, z czego 111,5 mln euro zostało skierowanych do realizacji przez polskie instytucje. Sektor „Kształcenie i szkolenia zawodowe” otrzymał 27,4 mln euro, „Młodzież” - 11,8 mln euro, „Edukacja szkolna” - 13,7 mln euro, „Edukacja dorosłych" - 4,2 mln euro. Uczelnie wyższe otrzymały ponad $54,3 \mathrm{mln}$ euro na organizację studenckiej wymiany czy tworzenie partnerstw strategicznych.

Realizacja programu Erasmus + koncentruje się na zwiększaniu kompetencji, nabywaniu wiedzy teoretycznej i praktycznej, pokonywaniu własnych słabości, przełamywaniu stereotypów. Korzyści z wnioskowania i udziału w projekcie są dla grupy docelowej niewymierne: nowe znajomości, wymiana doświadczeń, pozyskanie wiedzy o metodach pracy $\mathrm{w}$ krajach europejskich.

W roku 2016 Zespół Szkół Sióstr Salezjanek wnioskował o dofinansowanie i realizację projektu „Rozwój kariery bez bariery" w ramach programu Erasmus+. Dzięki temu w terminie od 1 czerwca 2016 r. - 31 maja 2017 r. realizowano ten projekt, a 18 września 2016 r. 15 uczennic i uczniów kształcących się na kierunku technik obsługi turystycznej z klas II, III oraz IV wyje- 
chało na trzytygodniowe praktyki zawodowe do Irlandii (fot. 5). Głównym celem projektu było podniesienie kwalifikacji uczniów, zwiększenie ich szans w zakresie mobilności i konkurencyjności na europejskim rynku pracy. Poprzez realizację projektu zamierzano doskonalić i kształcić nowe praktyczne umiejętności oraz kompetencje zawodowe $\mathrm{w}$ zakresie zgodnym z profilem technik obsługi turystycznej, jak również umożliwić nabycie doświadczenia zawodowego $\mathrm{w}$ pracy $\mathrm{w}$ przedsiębiorstwach turystycznych o wysokim standardzie świadczonych usług. Istotne było przygotowanie do pracy $\mathrm{z}$ wykorzystaniem nowoczesnych technologii oraz poprawa znajomości języka angielskiego poprzez bezpośrednie poznanie obcej kultury (fot. 6).

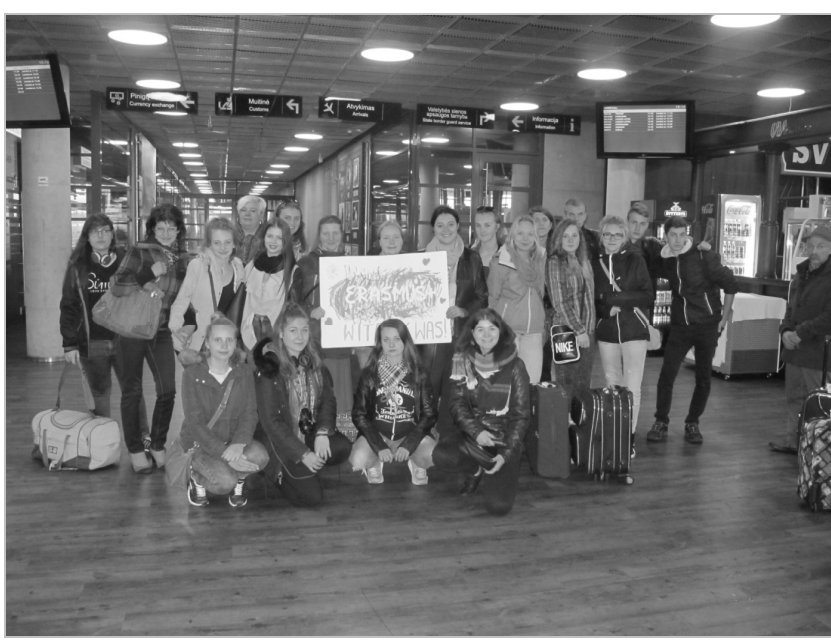

Fot. 5. Uczestnicy projektu na lotnisku Źródło: G. Mackiewicz

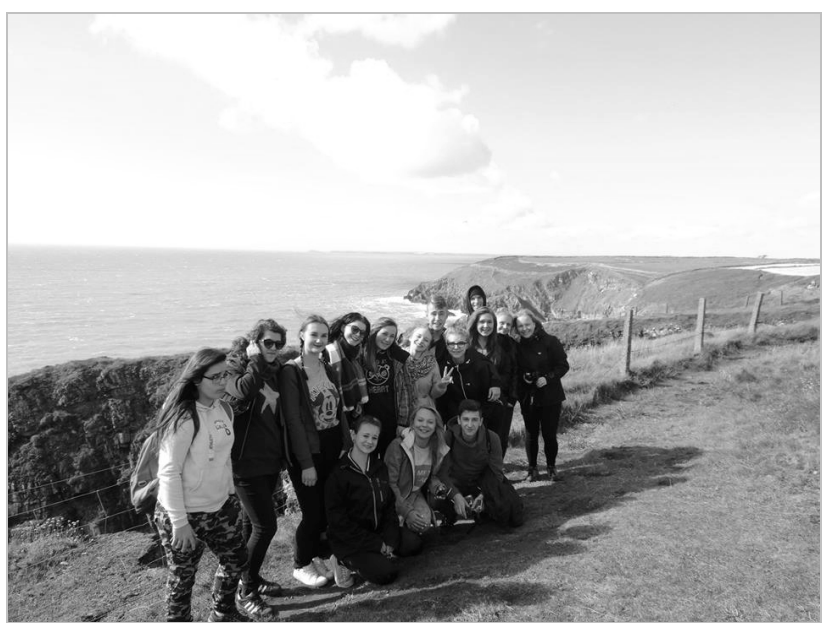

Fot. 6. Wycieczka krajoznawcza - południowa Irlandia Źródło: K. Jastak

Uczniowie wzięli udział w ankiecie, w której zdecydowanie zaznaczyli, że celem ich udziału w projekcie było podwyższenie kwalifikacji zawodowych,
12 osób chciało poznać warunki pracy w innym kraju, aż dla 11 celem było doskonalenie umiejętności z języka obcego, natomiast 10 osób chciało poznać nowe osoby, ale też zdobyć nowe doświadczenie życiowe i zawodowe, a dla ośmiu uczniów pobyt był sprawdzeniem własnej samodzielności. Ważne też było zdobycie certyfikatów potwierdzających pobyt oraz uzyskane dokumenty związane z mobilnością, takie jak: Europass Mobility (fot. 7).

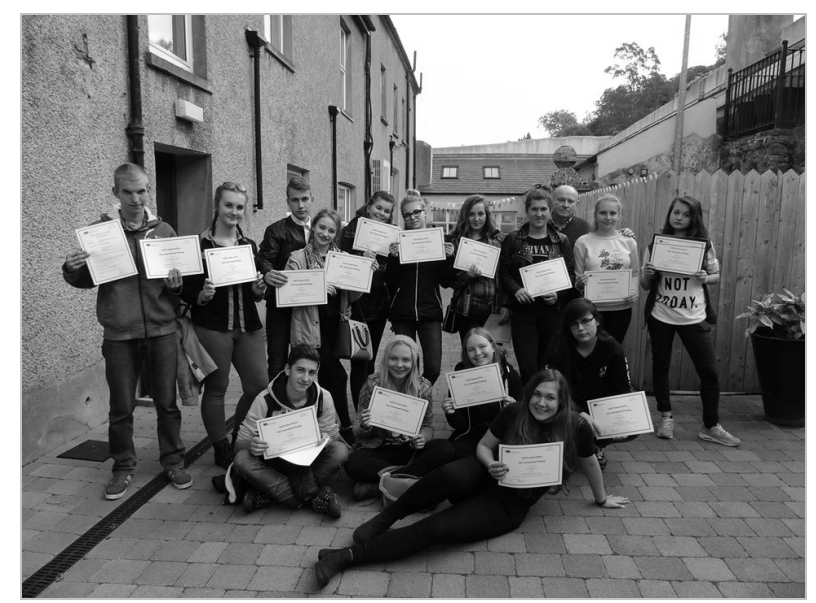

Fot. 7. Uczniowie z certyfikatami poświadczającymi odbycie kursu języka angielskiego Źródło: K. Jastak

Poprzez realizację wymienionych celów na bieżąco są wdrażane zmiany w zakresie podnoszenia standardu nauczania w naszej szkole, jak również nowoczesne metody pracy z uczniami. Uczniowie dzięki nabytym umiejętnościom praktycznym są przygotowani do poruszania się na europejskim rynku pracy, poznają nowe sposoby pracy, zwracają większą uwagę na jakość obsługi turysty oraz strój służbowy osób pracujących w ruchu turystycznym. Jednocześnie z raportów uczestników projektu czy ankiet badawczych wynika, iż zdobyli oni również wiele innych cech i umiejętności, takich jak: zwiększenie pewności siebie, chęć pokazania i stosowania zdobytej wiedzy w wykonywaniu konkretnych zadań. Praktykanci mieli bezpośredni kontakt z obcokrajowcami, mieszkali $\mathrm{w}$ rodzinach goszczących, zapewniono im dobre warunki lokalowe, pakiet kulturalno-językowy. Program pobytu przewidywał realizację uzgodnionego programu praktyk oraz dwie wycieczki krajoznawcze, kurs języka angielskiego, poznanie zabytków południowej Irlandii. Młodzież szczególnie doceniała otrzymane międzynarodowe dokumenty potwierdzające realizację staży, referencje od pracodawców, a w szczególności deklaracje pracodawców odnośnie do możliwości zatrudnienia po ukończeniu danego etapu kształcenia. Uczniowie wyjeżdżając na praktykę mieli wiele obaw co do znajomości języka angielskiego za- 
wodowego, a tymczasem otrzymali wsparcie i przekonali się o swoich umiejętnościach, przełamując barierę językową i kulturową. Na realizację projektu otrzymano dofinansowanie w wysokości 35804 euro.

W roku 2017 program Erasmus obchodził 30-lecie. Zainaugurowano uroczystość pod hasłem „Od Erasmusa do Erasmusa+. 30 lat programu, który zmienia życie Europejczyków". Jest to z pewnością jeden z najbardziej trafionych programów Unii Europejskiej ze względu na zapewnienie możliwości efektywniejszego kształcenia i nabywania doświadczeń dzięki wyjazdom zagranicznym. Zaplanowane działania będą z kolei okazją do podsumowań i refleksji, ale także poszukiwania kolejnych inspiracji.

\section{ZAKOŃCZENIE}

Opisane przykłady wykorzystania funduszy europejskich w kształceniu zawodowym miały na celu wsparcie uczniów Zespołu Szkół Sióstr Salezjanek im. Jana Pawła II w Suwałkach w zdobywaniu doświadczenia zawodowego, rozwijanie ich kreatywności oraz umiejętności społecznych. Kompleksowe działania w ramach zrealizowanych projektów dały uczniom solidne podstawy do ugruntowania wiedzy zawodowej, ułatwienie współpracy z pracodawcami poprzez poznanie ich oczekiwań i wymogów rynku pracy. Jednocześnie realizacja projektów korzystnie wpłynęła na rozwój samej szkoły. Dzięki funduszom unijnym otrzymano w pełni wyposażoną pracownię komputerową, a zakupione programy do nauki zawodu wykorzystywane są od sześciu lat do kształcenia kolej- nych roczników uczniów, a do tego społeczność szkolna i rada pedagogiczna korzysta z materiałów dydaktycznych. Starania o pozyskiwanie funduszy unijnych stały się działaniem naturalnym, wpisanym do Planu Rozwoju Szkoły.

\section{MATERIAŁY I ŹRÓDŁA}

Analiza kształcenia zawodowego $\mathrm{w}$ województwie podlaskim w kontekście działania 9.2 POKL sporządzona na zlecenie Urzędu Marszałkowskiego Województwa Podlaskiego, Warszawa, grudzień 2014.

DOROŻYŃSKI T., URBANIAK W., 2011, Rola funduszy strukturalnych EU w rozwoju instytucji edukacyjnych w regionie tódzkim, raport częściowy, Łódź.

Materiały informacyjne Departamentu Europejskiego Funduszu Społecznego, Urząd Marszałkowski Województwa Podlaskiego „Kształcenie zawodowe uczniów Działanie 9.2 Podniesienie atrakcyjności i jakości szkolnictwa zawodowego".

Materiały informacyjne „Fundusze Europejskie dla szkół na edukację" Oddział Funduszy Europejskich Departament Zarządzania Regionalnym Programem Operacyjnym, Urząd Marszałkowski Województwa Lubelskiego.

WIŚNIEWSKI J., 2012, Wykorzystanie środków na rzecz szkót z Priorytetu III oraz Priorytetu IX POKL, Uniwersytet Warszawski (publikacja wydana ze środków Unii Europejskiej w ramach Europejskiego Funduszu Społecznego), Warszawa.

Wykorzystanie środków UE w ramach Narodowej Strategii Spójności 2007-2013, styczeń 2016, Warszawa.

http://cku.zgora.pl/censym_zadania-70.php, 28.03.2017 r.

https:// www.power.gov.pl/strony/wiadomosci/fundusze-euro pejskie-na-reforme- szkolnictwa-zawodowego-kwalifikacjetechniczne-dla-gospodarki/ stan na 19.03.2017r.

https:// www.funduszeeuropejskie.2007-2013.gov.pl/dzialania promocyjne/Documents/FE_04_20_screen.pdf4.2017; 2.05. 2017. 